\title{
A comparison between Japanese and French cost management - Contingency and institutional perspectives
}

\author{
$14^{\text {th }}$ Asia-Pacific Management Accounting Association Conference, October $2^{\text {th }}$ \\ November $1^{\text {st }}$, 2018, Waseda University, Tokyo, Japan. \\ Gregory Wegmann \\ IAE Dijon School of management, University of Burgundy, France \\ gregory.wegmann@u-bourgogne.fr \\ Johei Oshita \\ Faculty of Economics, Kyushu University, Japan
}

\begin{abstract}
From an historical perspective, management accounting is a very recent phenomenon (see Johnson \& Kaplan, 1987) and is culturally grounded in a few old-industrialized countries, in Europe: Germany, United-Kingdom, France, but also in Japan and in the United-Stated. Notwithstanding the cultural dominance of English-speaking countries on management, nonEnglish speaking countries keep strong institutional and cultural roots that still influence their ways of managing companies. This is the case when looking at management accounting and more especially at cost accounting and cost management practices (now cost accounting/management).

This paper, based on contingency and institutional frameworks, explores what are the similarities and differences of Japanese and French cost accounting/management. The first part describes the theoretical background, the second part presents the Japanese context, the third part the French one and the fourth part discusses the question. The historical, institutional and cultural backgrounds of the two countries are reviewed, focusing on cost accounting / management with a view on target costing.

Through a comparative approach, specific French and Japanese ways of managing the costs are put in evidence. The research shows that the attitude towards target costing and the specific practices of cost accounting/management observed in France and Japan highlight the differences and similarities between the two countries. Both countries are also influenced by the Anglo-Saxon practices, and evidences of convergence become apparent.
\end{abstract}

Keywords: Japan, France, cost accounting, cost management, comparison 


\section{INTRODUCTION}

From an historical perspective, management accounting is a very recent phenomenon (see Johnson \& Kaplan, 1987) and is culturally grounded in a few old-industrialized countries, in Europe: Germany, United-Kingdom, France, but also in Japan and in the United-Stated. Notwithstanding the cultural dominance of English-speaking countries on management, nonEnglish speaking countries keep strong institutional and cultural roots that still influence their ways of managing companies. This is the case when looking at management accounting and more especially at cost accounting and cost management practices (now cost accounting/management).

This paper, based on contingency and institutional frameworks, explores what are the similarities and differences of Japanese and French cost accounting/management. It seems to be interesting to compare two non-English speaking countries, with strong cultural identities and a high level of internationalization of their companies. Because of these two strong cultural identities, Japanese and French companies have their own cost accounting/management practices, regardless of the influence of English-speaking countries, and particularly the United States.

The first part describes the theoretical background, the second part presents the Japanese context, the third part the French one and the fourth part discusses the question. The historical, institutional and cultural backgrounds of the two countries are reviewed, focusing on cost accounting / management practices with a view on target costing. So the paper considers practices concerning cost accounting/management in Japan and France, more than theory.

Through a comparative approach, specific French and Japanese ways of managing the costs are put in evidence. Both countries are also influenced by the Anglo-Saxon practices and this could also be the cause of convergence.

\section{THEORETICAL BACKGROUND}

Contingency theory states that universally applicable cost accounting/management systems which equally satisfy the needs of different organizations under different circumstances do not exist. However, generalizations for classes of business settings can be made. It is assumed that managers adapt their organizations to the contingencies in order to enhance performance. A specific setting of factors (contingent variables) matches certain aspects of cost accounting/management. Using the contingency theory requires to identify correlations between contingent variables and cost accounting/management systems characteristics by defining a contingency framework. Contingent variables are considered to be outside of the organization's control. Variables that are controllable by the organization are arranged to adapt to the contingencies in an appropriate configuration in order to improve performance (Otley, 1980).

To be able to distinguish between practices in different countries, contingent variables varying on a national level have to be identified. Numerous scholars have proposed a selection of contingent variables for comparative research on a national basis: Shields, (1998); Birkett (1998). Differences in culture are expected to impact cost accounting/management systems. Culture is the most frequently-stated influence factor in management accounting (Chow et al., 
1991 and 1999). The cultural framework of Hoftede ${ }^{1}$ (2001) is commonly applied by management accounting researchers (Carr and Tomkins, 1998). Because this research focuses on the characteristics and consequences of the differences between Japan and France, rather than on their cultural causes, these studies are only considered peripherally.

The institutional background and the economic situation of the particular country are also influence factors (Pistoni and Zoni, 2000; Shields, 1998, p. 505-506). Institutional theory focuses on the influences of the systems surrounding organizations (Scott, 2001). Institutions are social constructs directing actions while being sensitive to their influences (Granovetter, 1985). These institutions include both formal rules such as government policies, regulations and laws (economic orientation of institutional theory: North, 1990; Coase, 1998) and informal constraints such as norm of behavior, conventions and codes of conduct coming from cultural and social influences (sociological orientation of institutional theory: DiMaggio and Powell, 1983; Schein, 1985; Scott, 2001) and provide us with multiple insights (economic, social, and cultural) into economic phenomena (Polanyi, 1968). According to North (1981, 1990), allowance for institutions appears to be inescapable when evaluating corporate behavior. So firms are embedded (Granovetter, 1985) in a social, political, institutional, and cultural context. Their behaviors have to be compatible with certain socially accepted values, norms, and rules. In accordance with the neoinstitutional approach, firms are mainly looking for legitimacy (DiMaggio and Powell, 1983; Scott, 2001). DiMaggio and Powell distinguish three kinds of isomorphism: coercive (regulations coming from the authorities), normative (from an economic domain, certain professional associations, etc.), and mimetic (trying to be like other firms).

Grounded on an institutional perspective, Shields (in Bhimani; 1996) identifies seven factors that have shaped and currently influenced management accounting practices in European nations. These factors are: education, government, professional associations, consultants, technology, and the inter-nation transfer of information. With the same theoretical background, Ramirez (2001) puts in evidence four major determinants:

- The economical context,

- The professional context,

- $\quad$ The teaching contexts,

- $\quad$ The relationship with the authorities.

This theoretical background seems relevant for this study, looking at different types of institutional influences - traditions, politics, administration, academic, etc. — on Japanese and French cost accounting/management. The study is grounded on historical elements of French and Japanese traditions that enable to consider a tangle of institutional and economic factors affecting the characteristics of cost accounting/management systems.

Through a contingent, cultural and institutional framework to detect what are the most important and controversial problems in the field of cost accounting/management in France and Japan, the research focuses on the followings determinants:

- The origins of cost accounting techniques with the economic background of the countries,

- the management accounting profession and the teaching context,

- The relationship with the authorities,

- The inter-nations transfer of information: the influence of other countries on cost accounting/management,

\footnotetext{
${ }^{1}$ Hofstede (2001) develops the famous five dimensions of power distance, uncertainty avoidance, individualism vs. collectivism, masculinity vs. femininity and long versus short-term orientation.
} 
- Cultural influences on management styles with for instance decentralization/centralization and cooperative behaviors.

Mixing these determinants, the two next parts analyze respectively the Japanese and French contexts.

\section{COST ACCOUNTING AND COST MANAGEMENT IN JAPAN}

At first sight Japanese cost accounting/management practices seem to be relatively conventional and not dissimilar to Western practices. Looking back to traditions of cost accounting/management in Japan, nothing appears really specifically Japanese (Okano and Suzuki, 2007). But looking in more detail, specificities appear.

The first paragraph describes the Japanese cost accounting system and its specificities. The second paragraph analyses its determinants.

\subsection{Description of the Japanese cost accounting system}

Historically, Japanese companies have used direct costing systems. As the overhead costs increased, a department costing system was invented (Shimizu, p. 21-34). In this system, overhead costs are assigned to operating and support departments and costs in support departments are allocated to operating and other support departments through four full costing techniques: direct, step-down, grouping step-down and reciprocal.

Shimizu explains that few Japanese companies have experimented ABC (p. 24).

Using a questionnaire survey, Shimizu (2014) shows that the rate of overhead costs in Japanese companies is lower than in US companies, because the Japanese companies directly reduce overhead costs. Lean accounting (Maskell and Bagaley, 2003) clearly explains why with lean management practices overhead costs are reduced, with reductions of setup, batches and inspections costs, and thanks to inter-organizational cost management (Cooper and Slagmulder, 2004).

In the same inquiry Shimizu (2014) shows that $55.5 \%$ of the companies use a direct costing method and around $42 \%$ a full costing one with $24.1 \%$ using the grouping step-down method.

So, with all the techniques available, Japanese companies don't really need the ABC method and their allocation systems of overheads are quite effective. Some Japanese companies use a hybrid system combining step-down full costing method and Japanese Cost Accounting Standards (CAS) which is a good substitute for ABC systems (Shimizu, p. 30). The advantage of this system is that Japanese companies don't need to gather additional data, unlike ABC which is time and resource-consuming.

\subsection{Institutional and cultural decrypting}

When observing in depth the situation, due to the highly endemic cultural identity of Japan, the Japanese managers totally reinvented cost accounting/management. Japan is regarded as a collective and long-term oriented society (Hofstede, 2001). Institutional factors also show that permanent employment (Cole, 1979), flexibility and multi-skilling of the workforce (Nishimura, 2003) are widespread in Japan.

\subsubsection{The economical context}

After the period of isolation, and due to the Second World War, the Japanese industries were strongly influenced by the American way of doing management. For instance, Edward Deming came to Japan to advice leaders of Japanese industry, introduce the quality concept and influence the practices. Locke (1984) explained that the adoption by Japanese firms before 
the Second World War of German cost accounting techniques were overlaid by American practices after the Second World War. More recently, the reverse flow of Japanese target costing to America and Germany has been observed.

So a particular attention is paid to industrial and operational issues. In Japanese companies, what comes first are industrial and operational questions through the work of engineers setting up procedures and organizational innovations. In this context, cost accounting/management are primarily operational tools dedicated to engineers, middle managers and workers. Cost accounting/management do not exist alone, but are integrated in operational management systems such as just in time, quality control, and target costing.

A market orientation of cost accounting/cost management (see next part about target costing) quite developed.

- $\quad$ A distinct preference to non-financial, physical, concrete and operational data, contrary to American managers who privilege financial and global measures.

As explained Okano and Suzuki (2007), “...unlike the US where monetary terms were utilized in order for the State to rationally allocate resources, the Japanese seemed to have developed some distrust in the monetary valuations."

- Cost accounting/management systems are highly decentralized to be as close as possible to the field.

As Koike explains (1993, p.162), "NEC gradually separated its cost control activities from the core of the accounting division, and entrusted them as "autonomous activities" of each business division (...) NEC placed an emphasis on responsibility accounting, management by exception and Koto-mae (i.e., before-things-happen or causal) management."

Another factor that favors decentralized cost accounting/management is the characteristics of profit centers in Japan which are, according to Cooper (1995) "Microprofit Centers". Cooper observed in some Japanese companies the division of manufacturing, sales and support departments into small groups. Shimizu (2017, p. 136-147) describes the case of Kyocera, Corporation, a fine ceramics manufacturer. Products and sales departments of Kyocera are divided into small groups of five to ten people, called "amoebas", which are real microprofit centers. "Amoeba" leaders have to drive costs and make profits, using income statements (direct costing system) and a range of cost management indicators such as hourly efficiency, setting planned profits through an open book accounting philosophy.

A collaborative way of using cost accounting/management inside and outside the firm (e.g., McMann and Nanni, 1995; Yoshikawa, 1994, 2001).

With the Japanese-style transformation of quality control after the second world war, both buyers and suppliers should grow together and cost accounting/management became a common language (see the next part).

\subsubsection{The professional and educational contexts}

Hiramatsu (1992) accounts for a job rotation for accountants to other functions every five to ten years. Consequently, the degree of specialization in cost accounting/management is lower in Japan than in France. When it comes to the practical education (such as cost accounting), employees are trained essentially in-house and by job rotation, neither in universities (where the programs are more theoretical), nor in professional high schools (where the programs are practical but more elementary). Another characteristic of Japan's collectivism and long-term orientation is the seniority system: wages and promotions rely on seniority instead of performance (Kono and Falkus, 1984).

Due to the institutional and cultural factors described, the main characteristics of Japanese cost accounting/management are as follows: 
- $\quad$ Structures in Japanese companies are less specialized and management accounting is not professionalized. According to Hiramatsu (1992), accountants do not have any accounting major in $69.4 \%$ of Japanese organizations. Non-accounting departments have cost accounting/management responsibilities. More especially, design and production engineers are frequently involved in cost-reduction programs.

But recently, these features have gradually changed.

\subsubsection{Relations with the authorities}

They are regulations in the Cost Accounting Standards (CAS) in Japan since 1962. Even these standards are not compulsory, manufacturers still use them. CAS regulations are quite relative, according for instance to the classification of operating departments versus support ones and to the allocation of support departments.

Apart from these standards, the influence of the Japanese authorities on the formalization of cost accounting models in companies seems quite low as a diversity of practices as been observed (see 3.1). But even now, Japan Cost Accounting Association is actually considering the revision of CAS regulations in order to adapt them to new business circumstances (Takahashi (2016)).

Besides CAS regulations, it is necessary to remember that the three decades after the Second World War was just a time of government leadership in Japanese cost accounting/management. Nishimura (2003) shows that Japanese government leadership established modern management accounting in Japan by introducing advanced accounting system from USA after the Second World War. Especially the Ministry of international Trade and Industry (MITI)'s Industrial Rationalization Council played a critical role in promoting the spread of modern management accounting techniques. From July 1951 to the 1970s, MITI published many reports on modernization (Nishimura (2003, p.24)):

- July 1951, General Principles of Internal Control in Business enterprises

- February 1953, Outlines of Procedures related to Excursion of Internal Control

- July 1956, Profit Planning for implementation of Business Policy

- August 1960, Profit Planning in Division System of Business Enterprises

- November 1966, Cost Management

- $\quad$ 1972, The Coming Policy of Business Finance, etc.

And finally, Nishimura (2003), concerning the characteristics of post-war Japanese accounting methods, notes first that Japanese management accounting made much more use of the total control system than it did of strategic decision-making. This is because of the demands of foreign loans and the 'triangle' system of governments, main banks and companies. Second remark made by Nishimura is that Japanese companies made better use of human factors related to productivity than the dependency on professional strategic managers $(2003, \mathrm{p} .25)$.

\subsubsection{The inter-nation transfers of information}

If Japanese cost accounting/management seem at first quite similar to the Anglo-Saxon model, specificities finally emerge and remain from the practices.

Cost accounting/management in Japan are culturally grounded, considering a non-sense the Western quest for true cost and rejecting for instance activity-based costing. Cost accounting/management are mainly influential tools. In other words, costing is more important for decision making than for control purposes. Japanese management accountants are aware of overhead cost allocation problems, but they prefer cost information for influencing decisions and for motivating employees (Hiromoto, 1988). For instance, Japanese managers sometimes 
use to allocate overheads on a labor-cost base despite the fact that labor costs are only a small proportion of total costs. This allocation is made to focus design engineers' attention on increasing productivity through automation and for influencing employees, but not for giving information about the cost situation (Hiromoto, 1988). Due to the collectivist culture of the country, Japanese companies focus more on behavioral control and on motivating employees to reduce costs than on cost control.

According to Hutchinson and Liao (2009) who try to link the cost accounting/management practices to the Japanese philosophy, "Japanese management accountants have taken a Zen-like approach to developing cost accounting systems" (p.34). Considering that the perfect cost accounting system does not exist, the objective of management accountants is not so much to produce precise information. In this perspective, "Thinking about cost systems is more important than costing itself." (p.34) The objective of cost accounting is more to make employees act in accordance with the company's strategy. This philosophy is in accordance with the Strategic cost management stream (Shank and Govindarajan, 1989). In that sense, a kind of convergence between Japanese management accounting and a modernized approach of management accounting in Western countries can be detected.

The next part focuses on target costing and inter-organizational cost accounting to illustrate the specificities of cost accounting/management in Japan.

\subsubsection{An illustration of the Japanese context through target costing, inter-organizational cost accounting and other management practices}

As Feil et al. (2004, p.10) explain, early traces of target costing came from practices in US companies such as Ford. These practices were imported in Japanese companies after the Second World War. Then, the Japanese companies transformed these practices in what is called today target costing. In a sense, target costing is a "travel idea"2.

Even if Japanese scholars don't agree exactly on the same meaning of target costing, there is a global convergence on the fact that it is a global management process. During the early experiences, target costing was a more focus instrument dedicated to control the cost of purchases. But today, according to Oshita (1996), target costing is neither accounting nor costing in traditional meanings, rather it is frequent and mutual communicative act and strategy that enables comprehensive profit planning and management. The most famous Japanese academic experts share the same view (Kato, 1993; Monden \& Hamada, 1991; Sakurai, 1989; Tanaka, 1993; Tani et al., 1994).

The figure below (Oshita, 1996) illustrates this global view about the target costing process.

\footnotetext{
${ }^{2}$ Madsen \& Slatten (2015) describe the use of Balanced Scorecard in Scandinavian countries with the concept of "travel idea".
} 


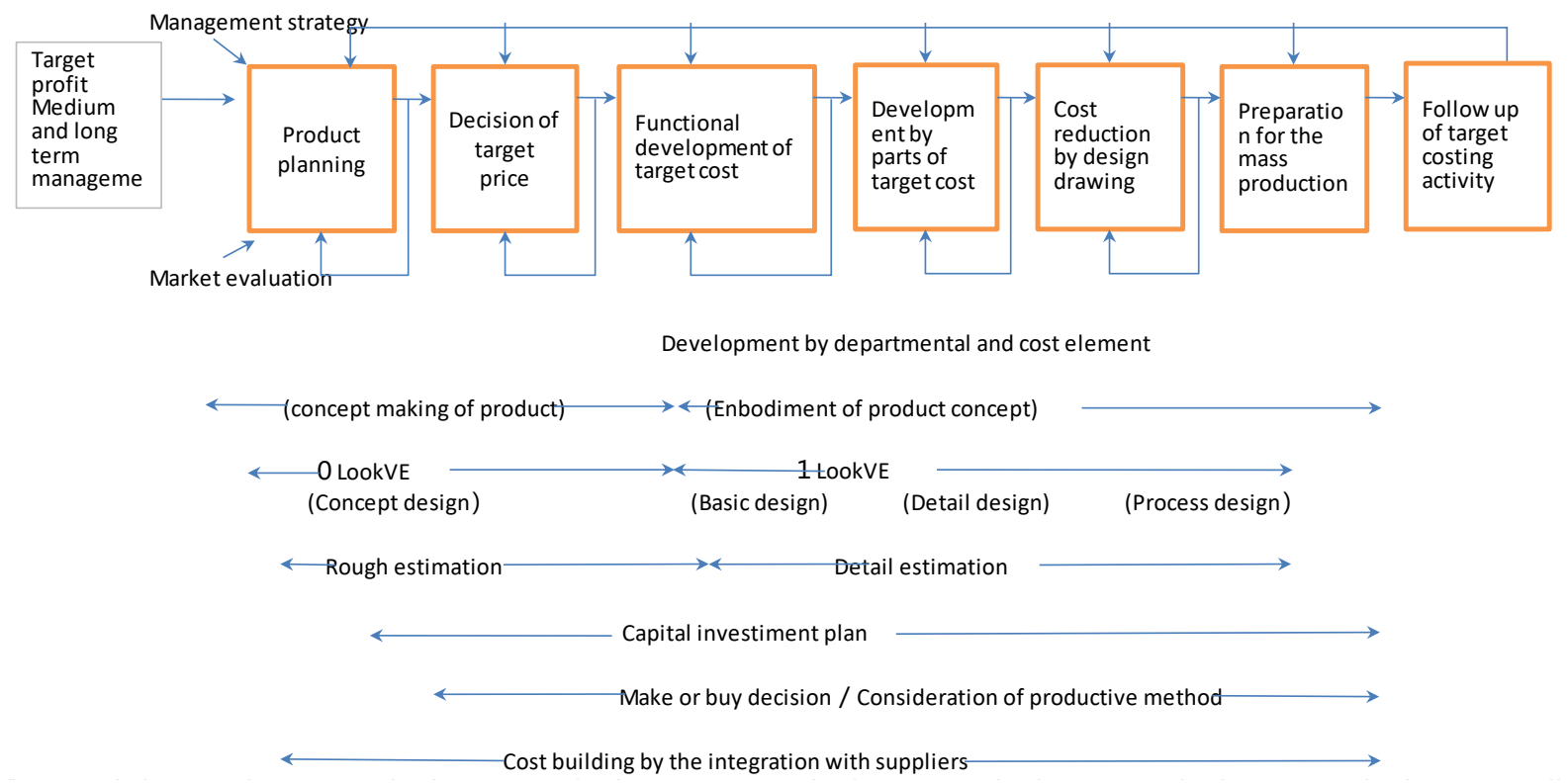

Note: From Japanese Accounting Association (1996, p.46)

Figure 1: Target costing, a global managerial system

The Japanese expression "genka-kikaku" may be misleading. It literally means "costplanning" and that is how target costing is regarded in Japan, rather than a costing method. "Genka-kikaku" has much to do with planning, coordination and improving in advance to actual production and its calculation. Some Japanese scholars focus more on market orientation of target costing (Hiromoto), while some others privilege the engineering dimension (Sakurai) and others the product aspect (Tanaka). But they all agree on the fact that target costing has become a global managerial and philosophical process. According to Kato (1993), target costing is not only a costing but a major element of a more global management system. Kato (p.43) also considers that target costing "...has its dysfunctional aspects..." and "should be socially and environmentally conscious".

So, an ideal form of target costing in Japanese companies is a comprehensive profit management system centering on planning, development and design of products. It is a global process with: the conceptual design (from product planning to target cost setting with various stages), the product development and design (core of the target costing), the transition to mass production and the follow-up. The process described comprises: methods of determining target costs, systems that support target costing activities and the organization for achieving target costs (with suppliers' relationships). An upstream management determination of the profit or cost, customer satisfaction and cross-functional cost determination in cooperation with suppliers complete this description. Considering a contingency approach, a target costing system is specified by the strategy and the form of the considered organization.

So, differences between a Western approach and the Japanese one mainly lies on the management philosophy concerning top leadership, team orientation, commitment to work and mutual work, education, the role of Keiretsu and information systems (Feil et al, 2004, p.17). Most Japanese employees have a cross-functional experience which facilitates to take part to target costing experiences.

Concerning the Keiretsu and the information systems, one important feature is the integration of cost management systems between suppliers and buyers. According to Cooper and Slagmulder (2004), inter-organizational cost management systems (IOCM) constitute a specificity of cost accounting/management in Japan. They describe for instance the case of 
engineers of two companies, Komatsu and Toyo, a large heavy industrial manufacturer and an independent manufacturer of heat exchange equipment involved in a supply chain, who initiate an inter-organizational cost investigation to optimize the costs. Target costing lies at the heart of IOCM because it links customer demands through product design to the parts acquisition process. The increased scope of the design changes enables the identification and implementation of greater cost savings across the entire supply chain. Two ways to reduce costs appear: by redesigning the product and its components and by changing the location of activities.

The next part presents the specificities of cost accounting/management in France.

\section{COST ACCOUNTING AND COST MANAGEMENT IN FRANCE}

Several contingency, cultural and institutional factors explain the specificities of the conventional French cost accounting system: a quite sophisticated system, mainly dedicated to industrial processes, with low managerial and predictive potentials.

The first paragraph describes this French conventional cost accounting system. The second paragraph analyses the determinants of this system.

\subsection{Description of the French conventional full cost accounting system}

Historically, the French cost accounting/management are highly influenced by full costing, privileging the multiplication of cost centers, drivers and the assignment of indirect costs to cost objects. The French cost accounting/management are historically separated from the budgeting system.

\subsubsection{The emergence of the French full costing system: an historical overview}

Compared to the Anglo-Saxon accounting system, the French accounting system is characterized by a net separation between cost accounting and financial accounting. Cost accounting is therefore in France explicitly developed for internal decision taking. France made an early contribution to the cost accounting literature (Nikitin, 1990).

Even if the French cost accounting system comprehends methods based on full- as well as on partial-costing, historical developments mainly focus on full costing. Research into cost accounting/management practices of French firms during the nineteenth century has focused on the implementation of industrial accounting around 1820 with the accounting for glass production of MGF (Manufacture des Glaces de France) and the works of Pierre-Antoine Godard-Desmarest, who was the owner of Baccarat Crystalworks and ran the firm from 1822 until 1839 (see Nikitin, 1990). MGF company distinguished between the three stages of the manufacturing process: pouring, abrasion, and polishing which led to an overall example of full process costing with a clear distinction between direct and indirect cost. The Baccarat industrial accounting system consisted of a double-entry bookkeeping system with cost calculations and production flow tracking at each stage of the manufacturing process. At the same period, in the field of mining, iron-making and sugar refining, Guilbault proposed the use of the average-cost method of pricing raw material into production and a process costing system with a distinction between fixed and variable overhead costs (Garner, 1954). The famous work of Lieutenant-Colonel Rimailho, with the Homogeneous sections method in military plants, confirmed this preponderance for full costing approaches. Early twentiethcentury French firms, like Renault, deployed such a full costing system. 
French cost accounting/management have strong industrial and engineering backgrounds, due to the context of their emergence. The French cost accounting techniques were developed amongst others from industrial practices. In this institutional context, the homogeneous sections-method is the main concept of the French cost accounting system in the first part of the twentieth century. A homogeneous section is a cost center organized around a main activity to enable the allocation of its costs to products or to other sections. This notion was applied to the French military industries during the 1920's thanks to Lieutenant-Colonel Rimailho (Lemarchand, 2002), who was head of the "Commission Générale d'Organisation Scientifique du Travail" (CGOST). Drawing on his military experience, Rimailho developed the homogeneous sections mechanism in such a way that, according to Lemarchand (Rimailho, 1928: 66; quoted in Lemarchand 2002) “...different specialized activities which make up the section are, in principle, employed in the same proportions for each task undertaken in the section". Renault, a major French car manufacturer developed sophisticated cost systems (Bhimani, 1993, 1996) during the 1920's based on Taylor's shop floor management system. Other French firms followed the example of Renault. The implementation of budgetary control systems started separately in the 1930s (Berland, 1997, 1998) and was based on a different process. Cost accounting and budgetary systems in the French tradition are two different cycles and the conventional cost process makes it difficult to draw a link between these two cycles. In fact, the cost analytical structure separates direct and indirect costs regarded cost objects. These cost objects are mainly products, which does not enable to put in evidence various kinds of margins based on the cost behaviors and the planning. To do that, a complex correspondence system that was difficult to implement at the time is required.

\subsubsection{The French full costing method}

The conventional French full costing method is a two-stage process. It is called today "Méthode des centres d'analyse" (Analysis centers method). This method is based on a hierarchical vision as described by Fayol's who defined the firm as a set of functions (Cauvin, Neumann, 2007). It assigns indirect costs to jobs or products in two stages. In the first stage, the method identifies indirect costs with various production and service departments. Service department costs are then allocated to production departments. The system assigns the accumulated indirect costs for the production departments to individual jobs or products based on predetermined departmental cost driver rates. The analysis centers could be viewed as cost pools. 


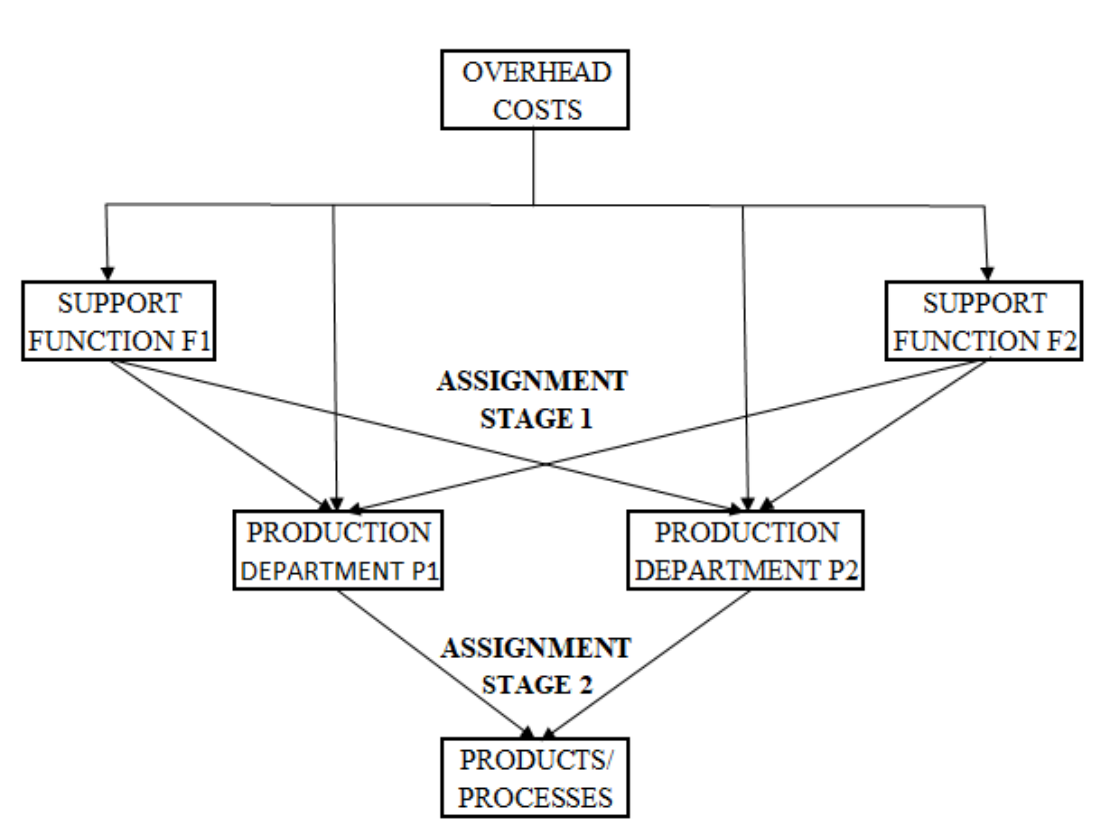

Figure 2: French full costing approach: The two-stage assignment process

These centers modelled on the production process are called the main sections when they contribute directly to the manufacture of a product. They are complemented by auxiliary sections that contribute indirectly to the manufacture of a product. The fundamental assumption of this two-stage allocation method is the absence of a strong direct link between the support activities and the products manufactured. For this reason, service department costs are first allocated to production departments using one of the conventional two-stage allocation methods previously described. This stage is called "primary repartition".

Once all charges have been either attached to a product or to a section, a physical quantity dedicated to the production of an output is defined for each center. Therefore, the users of the output (a product for instance) are charged for the output's quantity they consume. The cost per unit is the unit cost charged to the user for each unit physically consumed. It is most of the time a cost driver expressed in terms of quantities (number of direct labor hours, number of machine hours, etc.) During the process described, one important step is to establish the "indirect cost allocation table". This table gathers important information: the indirect costs of the centers, the primary and secondary repartitions and the costs of the units.

The next part analyses the institutional and cultural determinants of the system described.

\subsection{Institutional and cultural decrypting}

\subsubsection{The economical context}

France is an old industrialized country, with a centralized conception of the development of its industries. Since its early stages, French cost accounting/management are attached to the French industrial environment. The expression "industrial accounting" was used at that time and several features could be stated:

- $\quad$ The increasing competition experienced by French organizations after the 1820s, which facilitated the emergence of cost accounting/management to enhance productivity,

- $\quad$ The influence of the Scientific management movement (Taylorism), in relation to the strong influence of engineers in France, 
- In 1880's, the role of these French engineers who developed cost accounting techniques looking for measures for the industrial processes. These measures also aim to help reducing the transformation costs and supporting the mass production and the development of innovations. The focus was therefore more on production matters than on markets ones, compared to the USA.

- $\quad$ The French engineers had also at that time a social view of their role. They see cost accounting/management as instruments to regulate competition, to justify selling prices, to inform unions and to promote career advancement for employees.

- In addition to the role played by French engineers and the military industry (Lemarchand, 2002), the French centralized administration has been very influential.

After the Second World War, France had a State pricing policy. This context reinforced the role of the French administration and cost accounting remained influenced by government authorities through a full costing system. This context remained unchanged until the mid-1960s when demand exceeded supply and production capacity was saturated. The late 1960s saw the beginning of an era in which production capacity regularly exceeded demand. In this context, French full costing was challenged by the introduction of direct or variable costing, but managerial mentality was still strongly in favor of full costing. In the 1980's, Activity-based costing has been an opportunity for reopening the debate.

As a consequence, the main weakness of the French full costing system is the quite static approach of the costs analyzed that not permits contribution margins studies. Moreover, many studies have put in evidence homogeneity problems in a lot of centers that lead to crosssubsidization phenomena. Another weakness of the French full costing method is that it does not take into account capacity problems. For that reason, it needs to be completed with rational imputation. Another point is that it does not distinguish fixed from variable costs. So to summarize, the French full costing method needs to be completed by other systems: for planning, capacity problems, decision-making, etc.

\subsubsection{The professional and educational contexts}

In France, the accounting profession has a low level of recognition. The management accounting profession did not really exist until recently and the development of management accounting was mainly supported by the engineering profession. Levant and Zimnovitch (2013) explain that France was characterized by a dominant engineering culture during the 19th and 20th centuries and that the influence of Taylorism was high in France. So, during the 19th century, several French engineers work on cost accounting and develop high level of rationalization with sophisticated full cost systems. Burlaud and Simon (1981, p.22) explain that 'the French manner of product costing, embracing the idea of a 'complete cost' is an attempt to link scientific precision with practical policies. Their opinion is that while the procedure is rooted in the law, it also has gained popular acceptance due to the Cartesian element of the French psyche". It was also a way for engineers to strengthen their overall influence. French famous entrepreneurs like Renault had also an influence on the promotion of full costing.

As a consequence, a quite sophisticated, analytical and rational method became quite popular, the French homogeneous sections method. This method, dealing with indirect charges through cost centers resembles the German full costing method (see Lebas, 1994; Cauvin and Neuman, 2007). As explain Boyns et al. (1997 a, p.418), “... the slower development of the French accounting profession provided a window of opportunity for new ideas to be advanced..." with a major role played by the engineering profession. 
But, due to the professional situation described, the cost accounting and budgetary systems in the French tradition remained two different cycles and the traditional cost process makes it difficult to draw a link between these two cycles. It is still the case today. The cost analytical structure separates direct and indirect costs with reference to cost objects and a complex correspondence system, difficult to implement, tries to articulate the two cycles.

Concerning the teaching context in France, the development of management accounting was supported by practitioners and the Chambers of Commerce. Cost accounting and management training did not really exist in the French universities. So the French education system was characterized by a practical and technician orientation of the courses on cost/management accounting, without any academic background. Unlike Germany for instance, this situation generated in France a brake on innovation and a conservative view of accountants and management accountants.

\subsubsection{Relations with the authorities}

France has a long history of strong governmental influence with a powerful technocracy. It was the case since the origins of capitalism with mercantilism and state intervention in the economy (1630-1720). Bhimani (1994) described this situation with the "manufacture des glaces de France" (the Royal Glass Work) case, Boyns et al. (1997 b) through the industrial accounting during the nineteenth century and Nikitin (1990) with the costing system of SaintGobain about 1820 .

The French full costing system was institutionalized in the "Plan Comptable" (chart of accounts) with formal rules and fiscal matters which influenced the costing systems. Influenced by the German occupation of France, the chart of 1942 was very similar to the German plan of 1937 and was preserved after World War II. The French state continued to control cost accounting after World War II with the introduction of centralized planning and national accounts. As Levant and Nikitin (2012) explain, the French state played a major role in the separation of accounting systems and the failed attempt of the "système croisé" (dual system) to re-integrate them. The move towards standardization was so strong that the separation of accounting systems became inevitable.

As a consequence, the French state was a conservative factor. The influence of legal obligations on accounting policy was so strong that French firms were reluctant to divulge their costs and keep a strong separation between financial and cost accounting. French companies tended not change their cost accounting systems, allocating real costs to the products via the homogenous sections method.

But external influences must also be mentioned.

\subsubsection{The inter-nation transfers of information}

Lock (1984) describes the mutual influencing movements between countries, for example between Japan and the United-States, and between the United-States, France and Germany. Shield describes the American costing techniques in France and Germany in the 1920s, echoing Fordism and Taylorism.

Another major U.S. influence on French cost accounting/management dates back to the early years of the Marshall Plan (early 1950's). As a consequence, a number of leading French 
managers studied management accounting in the United States. Thus, an increased emphasis on budgeting and management control was observed in the following years.

More recently, the adoption of activity-based costing, balanced scorecard and target costing are good examples of the inter-nation transfers of information.

The next section analyzes the adoption of target costing in the French industry.

\subsubsection{About target costing in a French perspective}

For Western countries companies, target costing is more a technique than a global managerial philosophy (Feil et al., 2004). For the Japanese accounting association (Oshita, 1996), Western countries use a simplified picture of target costing.

In a French perspective (Oshita, 1996), target costing is first a market-oriented pricing system than a global system integrated in other systems. Due to the French analytical perspective, target costing is seen as a cost management system with a product life cycle approach. The starting point is the recognition of the discrepancy in timing between cost determination and accrual. For Lorino (1994), at the end of the target costing process, value and cost meet. So, among French scholars and practitioners today, there is still a debate to understand target costing as a true global management system or just as one tool among others.

\section{DISCUSSION AND CONCLUSION}

This paper compares Japanese and French cost accounting/management. It shows that there are specific French and Japanese ways of recognizing the concepts of cost accounting/management, different from the Anglo-Saxon approach. This first observation has justified the research objective.

Notwithstanding the homogenization of management practices around the world, Japanese and French cost accounting/management are keeping their traditions. French accounting looks like old-fashioned; but it is a wrong understanding. French cost accounting/management are just grounded on a strong analytical and control tradition. Differently, Japanese cost accounting/management are more synthetic and globally integrated to the whole management system of companies.

Through institutional, cultural and contingency approaches, several compared determinants between French and Japanese cost accounting/management traditions have been discussed. The research shows that the attitude towards target costing and the specific practices of cost accounting/management observed in France and Japan highlight the differences and similarities between the two countries.

The points raised are:

- The two countries traditions of cost accounting/management are rooted in an industrial history dominated by the role of the engineers, promoting rational, technical and manufactureoriented systems.

The weakness of the French and Japanese management accounting professions (compared to the Chartered institute of management accounting in United-Kingdom for example) backs up the industrial orientation of cost accounting/management in both countries. - The relationship with national authorities is quite different between France and Japan concerning cost/management accounting. France is a highly centralized country and the influence of state administration explains the usage of quite standardized and separated cost accounting systems, from a conservative perspective. French controllers focus more on the 
checking behind the control, while Japanese controllers could favor the steering. One reason is that French cost accounting systems focus on historical analyses and Japanese ones on planning. So, French managers need other information systems such as "Tableaux de bord" (dashboards) for decision making. French management accounting is rooted in two contradictory and complementary traditions (Lebas, 1994): a tradition of a standardized cost accounting system as a universally accepted method, the homogeneous section method (French full costing method), and a tradition of engineers, developing autonomous methods (GP/UVA method ${ }^{3}$ and French dashboards) and a strong interest for foreign methods such as activity-based costing and target costing. The French dashboard ("Tableau de Bord") focuses on monitoring physical and financial indicators for operational and strategic control (such as the balanced scorecard). Differently, cost accounting/management systems in Japan are adapted to the companies' operational needs. They are contextualized. Target costing is a global managerial method that needs to be fit to the specificities of each situation. Target costing is not a specific technique as the French full costing method, but a set of principles sustained by a managerial philosophy. - A "non-cooperative" culture of cost accounting/management in France, inside the companies and between them. As centralization is historically grounded in French companies, cost accounting/management can be perceived as instruments of dominance, controlled by experts and high level managers. French companies tend to favor centralized decision making systems. This is not the case in Japan and target costing is a good illustration of this difference. Target costing involves employees at the middle management and operational levels with selfcontrol mechanisms.

Cost accounting/management in Japan are more external-oriented than in France with a focus on customers, suppliers and partners. Target costing is a good illustration of this orientation. Concerning the cooperative dimension of Japanese cost accounting/management, companies in close business relations share common information through value chains. This is the case for instance in the automotive industry between main suppliers and constructors. Target costing is also a good illustration of this cultural trend with inter-organizational costing and open-book accounting approaches. In France, there is a reluctance to share costing information, even if target costing is now quite popular in French industries.

Both countries are also influenced by the Anglo-Saxon practices, and evidences of convergence seems to be emerging: the popularity of methods and trends such as balanced scorecard or the influence of IFRS (International Financial Reporting Standards). But these influences would only be on the surface and would not have a strong impact on managerial behaviors. But literature also indicates that Japan converges towards Western countries managerial behaviors. For instance, the seniority and permanent employment principles decrease in Japan (Pudelko, 2009). According to Hopper et al. (1999), several Japanese companies start generating more detailed cost information and adopting individualized payment systems. In France, the influence of English-speaking countries with the strategic cost management and strategic control trends shakes up traditions to move towards more external and strategic-oriented cost accounting/management systems. The Japanese influence with the lean management movement is also transforming the French habits.

Two proposals emerge from the research:

\footnotetext{
${ }^{3}$ GP-UVA is a French equivalent method first designed by Georges Perrin (GP) in the 50's; after, it was renamed UVA (value added units for "unités de valeur ajoutée") in the 80's. GP-UVA simplifies the calculations by fictively reducing multi-product firms to firms that only produce one product (see Levant and de la Villarmois, 2004).
} 
Proposal 1: Japan and French keep specific cost accounting practices despite the phenomena of globalization observed

Proposal 2: Due to cultural and institutional factors, the differences with which Japanese and French companies manage costs are even greater.

For a future research, it would be interesting to analyze in depth these subtle changes through case studies. A study about a Japanese subsidiary in France and a French subsidiary in Japan is planned.

\section{REFERENCES}

Berland, N. (1997). La naissance du contrôle budgétaire en France [The birth of budgetary control in France]. Comptabilité-Contrôle-Audit [Accounting-Control-Audit], 3(2), 522.

Berland, N. (1998). The Availability of Information and the Accumulation of Experience as Motors for the Diffusion of Budgetary Control: The French Experience from the 1920s to the 1960s, Accounting, Business and Financial History 8, 303-329.

Bhimani, A. (1993). Indeterminacy and the Specificity of Accounting Change: Renault 18981938, Accounting, Organizations and Society, 18, 1-39.

Bhimani, A. (1996). Management Accounting: European Perspectives, Oxford: Oxford University Press.

Birket, W. P. (1998). Management accounting in Europe: a view from down-under, Management accounting research, 9, 485-494.

Bouquin, H. (1995). Un aspect oublié de la méthode des sections : les enjeux d'une normalisation privée de la comptabilité de gestion [A forgotten aspect of the section method: The issues of private standardization of cost accounting], Revue Française de Comptabilité [French Review of Accouting], 271, 63-71.

Boyns, T., Edwards, JR \& Nikitin, M. (1997) (a). The Birth of Industrial Accounting in France and Britain. New York and London: Garland.

Boyns, T., Edwards J.R. \& Nikitin M. (1997) (b). The development of industrial accounting in Britain and France before 1880: a comparative study of accounting literature and practice, European Accounting Review, 6 (3), 393-437.

Burlaud, A. \& Simon C. (1981), Analyse des coûts et contrôle de gestion [Cost analysis and management control], Vuibert, Paris.

Carmona, S. (2006). The History of Management Accounting in France, Italy, Portugal, and Spain, Handbooks of Management Accounting Research, 2, 905-922.

Carr, C. \& Tomkins, C. (1998). Context, culture and the role of the finance function in strategic decisions. A comparative analysis of Britain, Germany, the U.S.A and Japan, Management Accounting Research, 9, 213-239.

Cauvin, E. \& Neuman, B. (2007). French cost accounting methods: ABC and other structural similarities, Cost Management, 21(3), 35-42.

Chow, C. W., Shields, M. D. \& Chan, Y. K. (1991). The effects of management controls and national culture on manufacturing performance: an experimental investigation, Accounting, Organizations and Society, 16 (3), 209-226.

Chow, C. W., Shields, M. D. \& Wu, A. (1999). The importance of national culture in the design of and preference for management controls for multi-national operations, Accounting, Organizations and Society, 24, 441-461.

Coase, R. (1998). The New Institutional Economics, The American Economic Review, 88, (2), 72-74. 
Cole, R. E. (1979). Work, Mobility and Participation. A Comparative Study of American and Japanese Industry, Berkeley Calif.

Cooper, R. \& Slagmulder, R. (2004). Interorganizational cost management and relational context, Accounting, Organizations and Society, 29 (1), 1-26.

Cooper, R. (1995). When Lean Enterprises Collide: Competing through Confrontation, Boston, MA: Harvard Business School Press.

DiMaggio, P.J., \& Powell, W.W. (1983). The Iron Cage Revisited: Institutional Isomorphism and Collective Rationality in Organizational Fields. American Sociological Review, 48, 147-160.

Feil, P., Yook, K.H. \& Kim, I.W. (2004). Japanese Target Costing: A Historical Perspective, International Journal of Strategic Cost Management, Spring, 10-19.

Garner, P. (1954). Evolution of Cost Accounting to 1925. Tuscaloosa, Alabama: University of Alabama Press.

Granovetter, M. (1985). Economic action and social structure: The problem of embeddedness. American Journal of Sociology, 91(3), 481-510.

Hiramatsu, K. (1992). Accounting education in Japanese corporations, Asian Review of Accounting, 1 (1), 57-68.

Hiromoto, T. (1988). Another Hidden Edge - Japanese Management Accounting, Harvard Business Review, 66 (4), 22-26.

Hofstede, G. H. (2001). Culture's consequences: Comparing Values, Behaviors, Institutions, and Organizations Across Nations. 2nd ed., (Thousand Oakes, CA).

Holzer, H.P. \& Rogers, W. (1990). The origins and developments of French costing systems (as reflected in published literature), Accounting Historians Journal, December, 17 (2), 57-71.

Hopper, T., Koga, T. \& Goto, J. (1999). Cost accounting in small and medium sized Japanese companies: an exploratory study, Accounting \& Business Research, 30 (1), 73-86.

Hutchinson, R. \& Liao, K. (2009). Zen Accounting: How Japanese Management Accounting Practice Supports Lean Management, Management Accounting Quaterly, Fall, 11 (1), 27-35.

Japanese Accounting Association (Special Committee). (1996). The Challenge of Research on Target Costing, Moriyama shoten (in Japanese).

Johnson, H.T. \& Kaplan, R.S. (1987). Relevance Lost: The Rise and Fall of Management Accounting, Harvard Business School Press, New York.

Kato, Y. (1993). Target costing support systems: lessons from leading Japanese companies, Management Accounting Research, 4, 33-47.

Koike, A. (1993). Profit Management System at NEC: An Essence of New Management (revised ed), Tokyo:Chuo Keizaisha. (in Japanese)

Kono, T. \& Falkus, M. (1984). Strategy and structure of Japanese enterprises, London.

Lebas, M. (1994). Managerial accounting in France Overview of past tradition and current practice, European Accounting Review, 3 (3), 471-488.

Lemarchand, Y. (2002). The Military Origins of the French Management Accounting Model: A Return to the Mechanisms of Accounting Change, Accounting History, 7 (1), 23-57.

Levant, Y. \& de la Villarmois, O. (2004). Georges Perrin and the GP cost calculation method: the story of a failure, Accounting Business and Financial History, 14 (2), 151-181.

Levant, Y. \& Nikitin, M. (2012). Can cost \& financial accounting be fully reintegrated? Accounting History, 17 (3-4), 437-461.

Levant, Y., Zimnovitch, H. (2013). Contemporary evolutions in costing methods: Understanding these trends through the use of equivalence methods in France, Accounting History, 18 (1), 51-75. 
Locke, R. (1984). The End of the Practical Man: Entrepreneurship and Higher Education in Germany, France, and Great Britain, 1880-1940, Greenwich, CT, JAI Press.

Lorino, P. (1994). Target Costing ou gestion par coût-cible [Target Costing or management by target cost], Revue Française de Comptabilité [French Review of Accounting], 255, 3545.

Madsen, D.O. \& Slatten, K. (2015). The Balanced Scorecard: Fashion or Virus? Administrative sciences, $5,90-124$.

Maskell, B.H. \& Bagaley. (2003). Practical Lean Accounting. A Proven System for Measuring and Managing the Lean Enterprise, Productivity Press.

McMann, P.J. \& A.J.Nanni,Jr. (1995). Means versus ends: a review of the literature on Japanese management accounting, Management Accounting Research, 6 (4), 313-346.

Monden, Y. \& Hamada, K. (1991). Target costing and Kaizen costing in Japanese Automobile Companies, Journal of Management Accounting Research, 3, Fall, 16-34.

Nikitin, M. (1990). Setting up an industrial accounting system at Saint-Gobain (1820-1880). The Accounting Historian Journal 17(2), 73-93.

Nishimura, A. (2003). Management accounting - Feed forward and Asian perspectives, Palgrave Macmillan UK.

North, D.C. (1981). Structure and Change in Economic History. New York: Norton.

North, D.C. (1990). Institutions, Institutional Change and Economic Performance. Cambridge: Cambridge University Press.

Okano, H. \& Suzuki, T. (2007). A History of Japanese Management Accounting, Handbook of Management Accounting Research, Edited by Christopher S. Chapman, Anthony G. Hopwood and Michael D. Shields.

Oshita, J. (1996). French Management Accounting: Industrial Accounting/ Analytical Accounting/ Management Accounting, Doudunkan (in Japanese).

Otley, D.T. (1980). The contingency theory of management accounting: Achievement and prognosis, Accounting, Organizations and Society, 5 (4), 413-428.

Pistoni, A. \& Zoni, L. (2000). Comparative management accounting in Europe: an undergraduate education perspective, The European Accounting Review, 9(2), 285-319.

Polanyi, K. (1968). The Economy as Instituted Process. In E. LeClair \& H. Schneider (Eds.), Economic Anthropology, 126-148, New York: Holt, Rinehart and Winston.

Pudelko, M. (2009). The End of Japanese-Style Management?, Long Range Planning, 42, 439462.

Ramirez, C. (2001). Understanding social closure in its cultural context: accounting practitioners in France (1920-1939), Accounting, Organizations \& Society, 26, 391 - 41

Sakurai, M. (1989). Target costing and how to use it, Cost Management, Summer, 39-50.

Schein, E. (1985). Organizational Culture and Leadership. San Francisco: Jossey-Bass.

Scott, W.R. (2001). Institutions and Organizations (2nd ed.). Thousand Oaks: Sage Publications.

Shank, J.K. \& Govindarajan, V. (1993). Strategic Cost Management, The Free Press.

Shields, M. D. (1998). Management accounting practices in Europe: a perspective from the States, Management Accounting Research, 9, 501-513

Shimizu, T. (2014). Cost Accounting Available to Practitioners, Tokyo, Japan: Chuokeizai-sha Inc. Written in Japanese.

Takahashi, F. (2016). Toward the Relevance Regain of Cost Accounting Standards, The Journal of Cost Accounting Research (Japan Cost Accounting Association), vol. 40 (1), 1-11 (in Japanese).

Tanaka, T. (1993). Target costing at Toyota, Journal of Cost Management, Spring 4-11. 
Tani, T., Okano, H., Iwabuchi, Y., Fududa, J. \& Cooray, S. (1994). Target cost management in Japanese companies: current state of the art, Management Accounting Research, vol. 5 (1), 67-81.

Yoshikawa, T. (1994). Some aspects of the Japanese approach to management accounting, Management Accounting Research, 5 (3-4), 279-287.

Yoshikawa, T. (2001). Cost accounting standard and cost accounting systems in Japan. Lessons from the past - recovering lost traditions, Accounting History Review, 11 (3), 269-281. 